\title{
Feeding Habits of the Spider Crab Libinia spinosa H. Milne Edwards, 1834 (Decapoda, Brachyura) in Ubatuba Bay, São Paulo, Brazil
}

\author{
Samara de Paiva Barros ${ }^{1,2} *$, Valter José Cobo ${ }^{1,2}$ and Adilson Fransozo ${ }^{2,3}$ \\ ${ }^{l}$ Laboratório de Biologia Marinha; Instituto Básico de Biociências; Universidade de Taubaté - UNITAU; Av. \\ Tiradentes, 500; 12030-180, Taubaté - SP - Brasil. ${ }^{2}$ Núcleo de Estudos em Biologia; Ecologia e Cultivo de \\ Crustáceos - NEBECC. 3Departamento de Zoologia e Botânica; Universidade Estadual Paulista - UNESP; \\ “Campus” de Botucatu; Distrito de Rubião Júnior; 18600-000; Botucatu - SP -Brasil
}

\begin{abstract}
The main goal of this study was the identification of the items of the diet of the L. spinosa, based on the stomach contents analysis. The crabs were obtained from Ubatuba region north-eastern shore of São Paulo State. In the laboratory, all the individuals were dissected, the stomach was retreated and fixed in 10\% formaline. The alimentary items were identified under stereomicroscope and analysed by the method of Frequency of Occurrence. A total of 194 stomachs was analysed and nine alimentary items were obtained. Unindentified material was found in 98\% of analysed stomach and poriferan were present in less then 1\% of stomachs. These results pointed a diversified diet explored by this crab, as well as the employment of some different methods for food intake. This suggested that these crabs could occupy different position in the trophic chain.
\end{abstract}

Key words: Stomach contents, alimentary itens, spider crab

\section{INTRODUCTION}

The Crustacea are viewed as one of the most important group of the marine macrofauna as a function of their diversity and abundance and generally represent a large part of the biomass on the marine ecosystems (Bertini, et al., 2004). Among these animals, the brachyuran crabs are present on the most of the aquatic food chains, occupying different trophic levels (Gouvêa and Queiroz, 1988; Rocha, et al., 1998). Decapod crustaceans show large diversity of alimentary behaviour that provides a diversified diet composition, including both mobile and sessile preys (Brown, et al., 1979; Carqueija and
Gouvêa, 1998). The use of different methods for food intake may be constrained by the environmental characteristic added to the availability of preys (Miller, 1961).

Investigations on the alimentary biology of the spider crab have been carried out by Paul, et al. (1979), Woods (1993) and Bernárdez, et al. (2000), and most on research efforts have been concentred on the ecological approach (Mantelatto et al., 2004). Investigations regarding the alimentary biology of crabs on the Brazilian coast remain scarce, being limited to some reports by Branco and Verani (1997), Brogim and Lana (1997), Carqueija and Gouvêa (1998), Mantelatto and Petraco (1997) and Branco et al. (2002).

\footnotetext{
Author for correspondence
} 
The spider crab L. spinosa H. Milne Edwards, 1834, belongs to the Majoidea superfamily, Pisidae family, and is found on the Brazilian coast from Espírito Santo to Rio Grande do Sul, and also Uruguayan and Argentinean waters (Martin and Davis, 2001; Melo, 1996). This investigation aimed to provide information on the diet composition of the spider crab $L$. spinosa on the north-eastern of São Paulo State by the analysis of stomach contend as well as the seasonal analysis of occurrence of the different food items.

\section{MATERIAL and METHODS}

Monthly collections were conducted from April to September 2001 on the Ubatuba bay, northeastern coast of São Paulo State $\left(23^{\circ} 25^{\prime} \mathrm{S}\right.$ $45^{\circ} 00^{\prime} \mathrm{W}$ ) (Fig. 1), by the double rig bottom trawl. All the material obtained was fixed in $10 \%$ formaline. In laboratory, only the adult crabs were dissected and stomachs were removed to analysis under stereomicroscope (40X magnificence). The stomachs contents were identified up to the class or order level, or until the possible taxon.

The alimentary items were identified by the method of Frequency of Occurrence (Willians, 1981), calculated by dividing the number of stomachs which contained a food items by the total number of stomachs observed. This method is considered to be the only method that can be rapidly applied to the analysis of stomach contents in crabs (Willians, 1981).

\section{RESULTS}

A total of 194 stomachs were analysed and 9 alimentary items were identified as described in Table 1. A large amount of advanced digested material was not possible to identify, hence was called unidentified material. Unindentified materials were recorded in $98 \%$ of crabs, showing the major percentage of occurrence in this study. In contrast, poriferan was found for less than $1 \%$ of stomachs (Fig. 2).

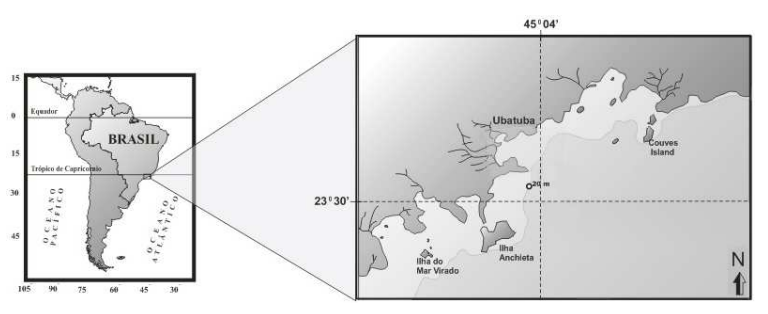

Figure 1 - Map of the region of catch of crabs

Table 1 - Composition and description of the alimentary items recorded in the stomach of spider crab $L$. spinosa.

\begin{tabular}{lc}
\hline Alimentary Item & Description \\
\hline Unindentified Material (UNM) & $\begin{array}{c}\text { advanced level of digestion. No distinctive characters could be } \\
\text { recognized. } \\
\text { Sediment (SED) } \\
\text { slgae (ALG) }\end{array}$ \\
Porifera (POR) & fragments of macro algae \\
Cnidaria (CNI) & represent by spicules \\
Mollusca (MOL) & Anthozoa fragments, of Gorgonacea order \\
Polychaeta (POL) & shell fragments, radulae, tentacles and corneous jaws of \\
Crustacea (CRU) & cephalopod \\
Fish (FIS) & body parts as jaws, parapodia and setae \\
\end{tabular}


The seasonal analysis of the food items frequency showed that the sediment was recorded during the entire period, with larger frequencies in July. The occurrence index other food items suffered large variation within the months. Preys as Porifera, Cnidaria, and Polychaeta were recorded in less than $10 \%$ of analysed stomachs. The major diversity of alimentary items in the crab stomach (Table 2) was recorded during May. It was important to note that no spider crabs were obtained during June, that justified its absence in the monthly analysis.

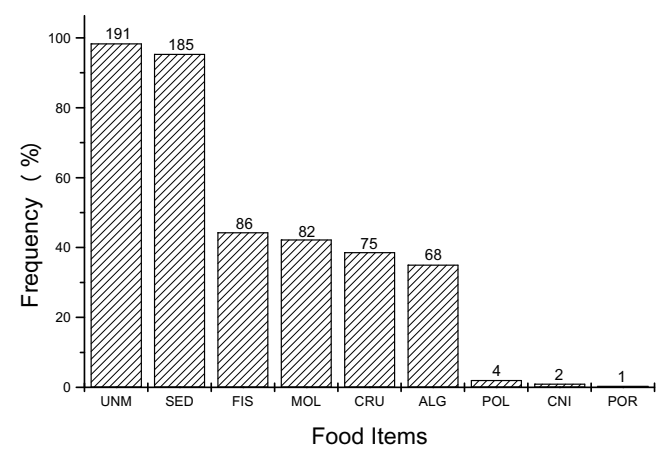

Figure 2 - Food items frequency of the spider crab L. spinosa. UNM, Unidentified material; SED, Sediment; ALG, Algae; POR, Porifera; CNI, Cnidaria; MOL, Mollusca; POL, Polychaeta; CRU, Crustacea; FIS, Fish. The numbers under the bars represent the absolute frequency of stomachs filled within determinate food item

Table 2 - Monthly percentage of stomachs filled with recorded food items for the spider crab $L$. spinosa.

\begin{tabular}{lcccccccccc}
\hline Month & \multirow{2}{*}{$\mathbf{N}$} & UNM & SED & \multicolumn{1}{c}{ FIS } & MOL & CRU & ALG & POL & CNI & POR \\
\cline { 3 - 11 } & & $\%$ & $\%$ & $\%$ & $\%$ & $\%$ & $\%$ & $\%$ & $\%$ & $\%$ \\
\hline April & 26 & 96.2 & 76.9 & 69.2 & 73.1 & 53.8 & 84.6 & 0.0 & 3.8 & 0.0 \\
May & 102 & 99.0 & 99.0 & 50.0 & 43.1 & 41.2 & 25.5 & 2.0 & 1.0 & 0.0 \\
July & 35 & 100.0 & 100.0 & 25.7 & 22.9 & 17.1 & 40.0 & 5.7 & 0.0 & 0.0 \\
August & 12 & 91.7 & 91.7 & 16.7 & 25.0 & 58.3 & 50.0 & 0.0 & 0.0 & 8.3 \\
September & 19 & 94.7 & 94.7 & 31.6 & 42.1 & 31.6 & 0.0 & 0.0 & 0.0 & 0.0 \\
\hline
\end{tabular}

N, number of analyzed stomachs; UNM, Unidentified material; SED, Sediment; ALG, Algae; POR, Porifera; CNI, Cnidaria; MOL, Mollusca; POL, Polychaeta; CRU, Crustacea; FIS, Fish.

\section{DISCUSSION}

The diet characterisation as generalist or specialist requires more than the simple numeric relationship of consumed items, and depends on the food origin (e.g. animal or plant) and on the mobility degree of these alimentary items (Kapusta and Bemvenuti, 1998). In this sense, the results showed that $L$. spinosa consumed both sessile and mobile preys. A large amount of unidentified material was found in the stomach that was the result of an advanced digestion degree. Crustacean jaws and gastric mills provide food triturating. This action makes the food material an unidentified mass item, and suggests that these crabs present a high digestive ratio.

Among the crustacean macrofauna, most of the Decapod present slicer chelipeds that allows to ingest the prey by pieces, which also make the identification of those alimentary items difficult (Willians, 1981; Petti, 1990; Branco and Verani, 1997). According to Branco and Verani (1997), the presence of the substrate grains in the crab diet suggested the deposit feeder behaviours, 
considering the nutrition value of the microorganisms that colonised these grains. However, Carqueija and Gouvêa (1998) didn't consider the sediment as alimentary item and supported its accidental ingestion attached to other alimentary compounds. Both, the deposit feeder and accidental ingestion hypothesis could be possible to explain the presence of sediment in the $L$. spinosa stomachs. However, only laboratory studies can offer an adequate answer to this question.

The importance of plant items is also questionable within brachyuran crabs. However, Paul (1981) investigating the diet of blue crab Callinectes arcuatus and Callinectes toxotes discussed the presence of plant material as a result of selective consume, accidental ingestion or even inside the gut's prey. Branco and Verani (1997) supported that the presence of plant material on the crab's stomach was an accidental ingestion. In contrast, Lacerda et al. (1991) found some marine algae that grew on the tree branches as a principal food item for Aratus pisonii, and could not considered as an accidental ingestion. The large frequency of plant material in the L. spinosa stomachs suggested the selective use of this item as food resource.

Predation methods are also used by $L$. spinosa to take food, apparently as an opportunistic predator, catching sedentary or debilitated preys or even dead animals that could explain the presence of agile preys as fish and cephalopod mollusks. Opportunistic predation for Hepatus pudibundus was also reported by Mantellato and Petraco (1997), from the same region as of the present investigation.

The low frequency of alimentary items such as Porifera, Cnidaria and Polychaeta in the crab stomach, could be caused by the items consumed which wose the portion of unidentified material. According to Gonzáles-Gurriaram (1978) and Petti (1990), crustacean eggs present in the crab's stomachs were commonly caused by some the stress condition in the situation when the female might ingest its own eggs. In another view, eggs are yolk store, and could represent an additional source of food. This fact became ovigerous crustacean female's targets of predators. Besides these facts it is important to consider the eventual ingestion of demersal eggs.

The analysis of the diet composition of $L$. spinosa suggested that this crab was able to employ different methods to get food that allowed it to consume infaunal and epifaunal preys, sessile, mobile, sedentary and even agile animals as food items. The results suggested that this crab species could be considered as member of various degrees on trophic chain.

\section{ACKNOWLEDGEMENTS}

The authors are indebted to the colleagues of the Laboratório de Biologia MarinhaLabBMar/UNITAU e NEBECC/UNESP for their help during this study. Also thanks the Conselho Nacional de Desenvolvimento Científico e Tecnológico (CNPq-114684/03-0) that provided grants Barros, S.P. The authors are also grateful to $\operatorname{Dr}^{\mathrm{a}}$ Janet W. Reid for the revision of the English version.

\section{RESUMO}

O objetivo deste trabalho é identificar os itens alimentares que compõem a dieta de $L$. spinosa, por meio da análise do conteúdo estomacal. Os caranguejos foram coletados no litoral norte paulista $\left(23^{\circ} 25^{\prime} \mathrm{S}-45^{\circ} 00^{\prime} \mathrm{W}\right)$. No laboratório, todos indivíduos foram dissecados, os estômagos foram retirados e fixados em formol $10 \%$. Os itens alimentares foram identificados sob estereomicroscópio, sendo que para a análise foi utilizado o método Frequiência de Ocorrência. Foram analisados 194 estômagos, nos quais foram encontrados nove itens alimentares. A maior freqüência foi para material não identificado, ocorrendo em $98 \%$ dos estômagos analisados e Porifera foi $\mathrm{o}$ item com a menor frequiência, ocorrendo em menos de $1 \%$ dos estômagos. Com base nos resultados obtidos, sugere-se que $o$ caranguejo L. spinosa apresenta uma dieta diversificada, sugerindo a utilização de diferentes métodos para a obtenção de alimento e por consequiência podendo ocupar vários níveis na cadeia trófica.

\section{REFERENCES}

Bernárdez, C.; Freire, J. and Gonzáles-Gurriarán, E. (2000), Feeding of the spider crab Maja squinado in rocky subtidal areas of the Ría de Arousa (north-west Spain). Journal of the Marine Biological Association of the United Kingdom, 80, 95-102. 
Bertini, G.; Fransozo, A. and Melo, G. (2004), Biodiversity of brachyuran crabs (Crustacea: Decapoda) from non-consolidated sublittoral bottom on the northern coast of São Paulo State, Brazil. Biodiversity and Conservation, 13, 2185-2207.

Branco, J.O. and Verani, J.R. (1997), Dinâmica da alimentação natural de Callinectes danae Smith (Decapoda) na Lagoa da Conceição Florianópolis, Santa Catarina, Brasil. Revista Brasileira de Zoologia, 14, 1003-1018.

Branco, J.O.; Lunardon-Branco, M.J.; Verani, J.R.; Schveitzer, R.; Souto, F.X. and Vale, W.G. (2002), Natural diet of Callinectes ornatus Ordway, 1863 (Decapoda, Portunidae) in the Itapocoroy Inlet, Penha, SC, Brazil. Brazilian Archives of Biology and Technology, 45(1): 35-40.

Brogim, R.A. and Lana, P.C. (1997), Espectro alimentar de Aratus pisonii, Chasmagnathus granulata e Sesarma rectum (Decapoda, Grapsidae) em um manguezal da Baía de Paranaguá, Paraná. Iheringia, Série Zoologia, 83, 35-43.

Brown, S.C.; Cassuto, S.R. and Loos, R.W. (1979), Biomechanics of chelipeds en some decapod Crustacea. Journal of Zoology, 188, 143-159.

Carqueija, C.R.G. and Gouvea, E.P. (1998), Hábito alimentar de Callinectes larvatus Ordway (Crustacea, Decapoda, Portunidae) no manguezal de Jiribatuba, Baía de todos os Santos, Bahia. Revista Brasileira de Zoologia, 15, 273-278.

Gonzáles-Gurriaram, E.G. (1978), Introducción al estúdio de la alimentación necora Macropipus puber L. (Decapoda, Brachyura). Boletim del Instituto Español de Occanografia., 4, 82-90.

Gouvêa, E.P. and Queiroz, E.L. (1988), Braquiúros (Crustacea, Decapoda) utilizados na alimentação de peixes Rajidae no litoral sul do Brasil. Ciência $e$ Cultura, 40, 276-279.

Kapusta, S. C. and Bemvenutti, C. E. (1998), Atividade nictimeral de alimentação de juvenis de Callinectes sapidus, Rathbun, 1895 (Decapoda, Portunidae) numa pradaria de Rippia maritima L. e num plano não vegetado, numa enseada estuarina da Lagoa dos Patos, R.S., Brasil. Nauplius, 6, 41-52.

Lacerda, L.D.; Silva, C.A.R.; Rezende, C.E. and Martinelli, L.A. (1991), Food sources for the mangrove tree crabs Aratus pisonii: a carbon isotopic study. Revista Brasileira de Zoologia, 51, 685-687.

Mantelatto, F.L.M. and Petracco, M. (1997), Natural diet of the crab Hepatus pudibundus (Brachyura: Calappidae) in Fortaleza bay, Ubatuba (SP), Brazil. Journal of Crustacean Biology, 17, 440-446.
Mantelatto, F.L.M.; Faria, F.C.R.; Biagi, R. and Melo, G.A.S. (2004), Majoid crabs community (Crustacea: Decapoda) from infralittoral rocky/sandy bottom of Anchieta Island, Ubatuba. Brazilian Archives of Biology and Technology, 47(2): 273-279.

Martin, J.W. and Davis, G.E. (2001), An updated classification of the recent Crustacea. Science Series 39. Natural History Museum of Los Angeles County, Los Angeles, California.

Melo, G.A.S. (1996), Identificação dos Brachyura (caranguejos e siris) do litoral brasileiro. São Paulo, Plêiade.

Miller, D.C. (1961), The feeding mechanisms of fiddler crabs, with ecological considerations of feeding adaptations. Zoology, 46, 84-100.

Paul, R.K.G. (1981), Natural diet, feeding e predatory activity of the crabs Callinectes arcuatus e Callinectes toxotes (Decapoda, Brachyura, Portunidae). Marine Ecology - Progress Series, 6, 9199.

Paul, A. J.; Feder, H. M. and Jewett, S. C. (1979), Food of the snow crab, Chionoecetes bairdi Rathbun, 1924, from cook inlet, Alaska (Decapoda, Majidae). Crustaceana, Suppl. 5, 62-68.

Petti, M.A.V. (1990), Hábitos alimentares dos crustáceos decápodas braquiúros e seu papel na rede trófica do infralitoral de Ubatuba, Litoral Norte do Estado de São Paulo, Brasil. Dissertação de Mestrado, Universidade de São Paulo, São Paulo.

Rocha, G.R.A.; Gasalla, M.A.; Rossi-Wongtschowski, C.L.D.B; Soares, L.S.H.; Pires-Vanin, A.M.S.; Muto, E.Y; Cergole, M.C.; Aidar, E.; Mesquita, H.S.L.; Mesquita, S.M.L. Gianesella-Galvão, S.M.F.; VejaPerez, L.A. and Jarre-Teichmann, A. (1998), Quantitative model of trophic interactions in the Ubatuba shelf system (Southeasthern Brazil). Fishbyte, 21, 25-32.

Willians, M.J. (1981), Methods for analysis of natural diet in portunid crabs (Crustacea: Decapoda; Portunidae) Journal Of Experimental Marine Biology And Ecology, 52, 103-113.

Woods, C. M. C. (1993), Natural diet of the crab Notomithrax ursus (Brachyura: Majidae) at Oaro, South Island, New Zealand. New Zealand Journal of Marine and Freshwater Research, 27, 309-315.

Received: March 14, 2006; Revised: July 14, 2006; Accepted: July 11, 2007. 